\title{
Migration Strategies of Common Buzzard (Buteo buteo Linnaeus, 1758) in Dobruja
}

\author{
Cătălin-Răzvan STANCIU1', Răzvan ZAHARIA², Gabriel-Bogdan CHIȘAMERA4, \\ Ioana COBZARU ${ }^{3, *}$, Viorel-Dumitru GAVRIL ${ }^{3,1}$, Dumitru MURẢRIU3
}

${ }^{1}$ Faculty of Biology, University of Bucharest, 91-95 Splaiul Independenței, 5050095 Bucharest, Romania ${ }^{2}$ Oceanographic Research and Marine Environment Protection Society Oceanic-Club, Constanța, Romania ${ }^{3}$ Institute of Biology Bucharest of Romanian Academy, 296 Splaiul Independenței, 060031 Bucharest, Romania

4"Grigore Antipa" National Museum of Natural History, 1 Kiseleff Blvd., 011341, Bucharest, Romania *corresponding author, email: ioana.cobzaru@ibiol.ro

Received: August 2, 2017; Accepted: August 31, 2017; Available online: August 31, 2017; Printed: December 31, 2017

\begin{abstract}
We studied various aspects regarding migration behavior of the Common Buzzard for two subspecies $(B . b$. buteo and $B . b$. vulpinus) transiting the region which overlaps with the Western Black Sea Corridor. Using vantage points set across Dobruja we managed to count 2,662 individuals. We highlighted the seasonal and diurnal peak passage, flight directions and height of flight for each season. Our results suggest that $57 \%$ of the counted individuals belongs to long-distance migrant Steppe Buzzard - B. b. vulpinus. The peek passage period in autumn migration was reached between the $26^{\text {th }}$ of September to the $6^{\text {th }}$ of October, while for the spring migration peek passage remained uncertain. The main autumn passage direction was from N to S, and NNW to SSE but also from NE to SW. For spring passage the main direction was from $\mathrm{S}$ to $\mathrm{N}$ but also from ESE to WNW. Flight height during autumn migration was mostly at high altitude while in spring migration was more evenly distributed. The most significant activity was recorded in the second time period, between 10:01 and 13:00 (43\%).
\end{abstract}

Key words: Common Buzzard, Buteo buteo, migration, Dobruja, Romania

\section{INTRODUCTION}

Migratory behavior of long distance migrants has been well described for many species, but not the migratory strategies of partial migratory birds. In the case of raptors from Central and Eastern Europe migratory behavior is relatively unclear for most species, detailed information are predominantly available only for populations from Northern Europe (Meller et al., 2013; Holte et al., 2016). Birds move between breeding grounds every autumn to migrate to areas with more favorable conditions. Many travel only over a few hundred kilometers but others cover huge distances (Gwinner, 1990; Newton, 2010). Migrating raptors use two main flight styles: soaringgliding and flapping-gliding (Spaar, 1997; Spaar \& Bruderer, 1997). The Common Buzzards, as other soaring birds, especially during migration take advantage of the convection phenomenon, choosing a flight route, which will short up the time required for ascension to the right height for gliding flight. This can be done by flying over a thermal source as it flies in the desired direction, then gently rising and gaining altitude until it enters the strong, descendant currents, which is fast moving towards a new thermal source (Nisbet, 1962). A Common Buzzard reduces its energy consumption by $3 / 4$ gliding flight than in active flight (Alerstam, 1990).

The Common Buzzard (Buteo buteo) is one of the most robust species of raptors in the western Palearctic with numerous races through its entire range (Génsbøl, 
2008). Two to three subspecies were recognized so far from Romania, the Common Buzzard (Buteo buteo buteo) and the Steppe Buzzard (Buteo buteo vulpinus), recorded as breeding and regular migratory by various authors (Paşcovchi \& Manolache, 1971; Cătuneanu et al., 1972), and Buteo buteo menetriesi, recorded as "very rare" by Paşcovchi \& Manolache (op. cit.). During autumn migration and winter, the resident buzzard population is increased by individuals coming from northern areas, which are making short migrations to winter in Romania, including Dobruja.

The Common Buzzard is considered to be mainly resident, with individuals of the Nordic populations migrating to central and western parts of Europe and individuals from Sweden even wintering in North-West Africa in Morocco (Forsman, 2010). This subspecies spends the winter on the European side of the Mediterranean Basin, with very few specimens crossing the Mediterranean Sea to winter in Tunisia (Panuccio, 2011; Cramp \& Simmons, 1987). At the south of the Baltic Sea, populations show a lower seasonal dynamics, being almost sedentary (Strandberg et al., 2009).

The Steppe Buzzard spreads across Europe in the Scandinavian Peninsula and Ukraine to the North, to the East of the Balkan Peninsula in the South, and to the West to Siberia on the Yenisei River, northern Kazakhstan and the Altai Mountains. Almost all individuals of the Steppe Buzzard, nesting in the region between Scandinavia and Ukraine to the West and up to $90^{\circ}$ East, are wintering in Africa and avoid crossing the sea over long distances (Moreau, 1972). Without distinguishing between the two subspecies (B. b. buteo and B. b. vulpinus), Bildstein (2006) considers the species to be a partial migrant (with less than $90 \%$ of the total number of individuals migrates) and show that the maximum distance they cross over the seas is about $25 \mathrm{~km}$.

The migration of the Steppe Buzzard from wintering to breeding areas in Europe and back, takes place on two migration corridors of the Eurasian-East African route, mainly through the Caucasus on the Trans-Caucasian Corridor and above the Bosporus Strait on the Western Black Sea Corridor. The largest numbers recorded during the autumn migration that passed through the East of the Black Sea (the Trans-Caucasian Corridor) were recorded between the $18^{\text {th }}$ of August and the $10^{\text {th }}$ of October 1976, when 204,959 individuals were observed in North-eastern Turkey, with a peak of migration of 134,773 individuals on the $28^{\text {th }}$ of September (Cramp \& Simmons, op. cit.), as well as in autumn of 2016, when 225,583 individuals were seen in Batumi (Georgia) heading South to the winter quarters (Batumi Raptor Count, 2006). On the western side of the Black Sea (Via Pontica), smaller numbers of this migratory species were recorded compared to those passing through the East, thus only 32,895 individuals were observed in the autumn of 1969, 24,615 individuals in 1972, respectively 205,000 individuals in 1976 , with migration peaks registered between the $22^{\text {nd }}$ of September to the $2^{\text {nd }}$ of October. For spring migration, the peak passage time is uncertain, probably from late March to mid-April (Cramp \& Simmons, op. cit.). The Steppe Buzzard which are transiting Dobruja during migration to the wintering areas in Africa, comes from Finland, eastern Russia, Belarus and Ukraine. Depending on weather conditions, they can stop for resting or feeding, but without exception all individuals continue their way South.

Based on original observations in Dobruja, we analyzed and discussed the migration strategies for the Common Buzzard in South-eastern Romania.

\section{MATERIAL AND METHODS}

The study site was located in South-eastern Romania, in Dobruja, a territory between the Danube and western shore of the Black Sea. Along four years (2012-2015), 
during the spring and autumn migration, we gathered observations regarding the Common Buzzard migration using vantage points. Observation points $(\mathrm{n}=30)$ were set considering a $2 \mathrm{~km}$ visibility of the observer, covering a significant part of the studied area (Fig. 1).

Taking into account that in the Black Sea region, the range of the Steppe Buzzard (Buteo buteo vulpinus) and of the Common Buzzard (Buteo buteo buteo) overlaps, and that the subspecies can be sometimes difficult to distinguish (Pașcovschi \& Manolache, 1971; Forsman, 2016), we considered as Steppe Buzzard only the clear

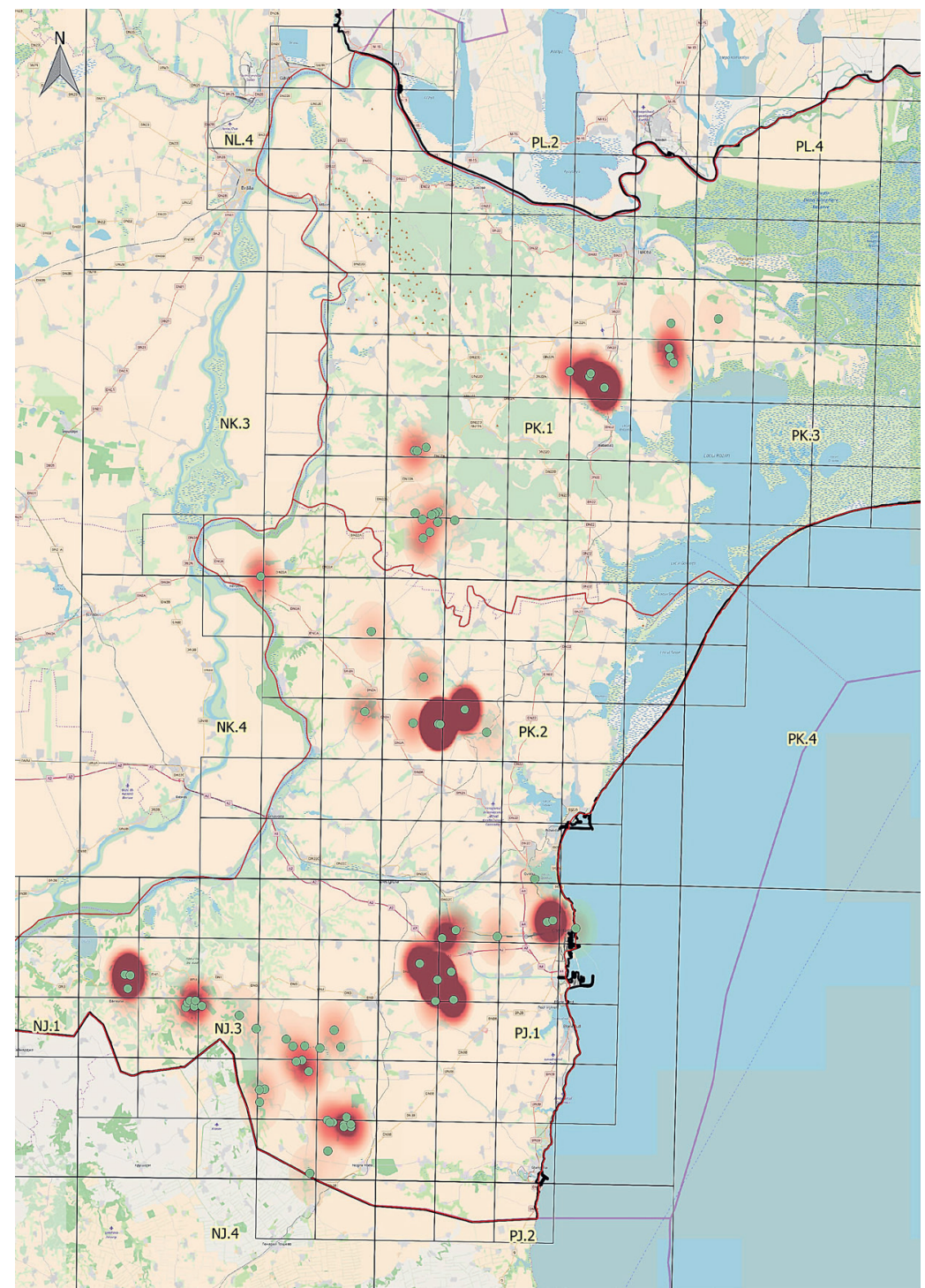

Fig. 1 - Dobruja map (UTM 10x10 km): Green dots - vantage points, Red spots - number of individuals intensity heatmap. 
identified individuals, the rest being recorded as Common Buzzards, including both possible subspecies.

The main aspects recorded in the field for the target species were the subspecies, when possible, the number of individuals, flight height, flight direction, GPS location, time and date. In order to estimate as accurately as possible the flight height of the observed birds, we used fixed landmarks whose height is well known, such as the height of a wind turbine. We have considered wind turbines with a tower height of 100 meters, adding 50 meters, the length of the blade, reaching a total height of 150 meters. Taking into account that the wind energy sector is very well developed in Dobruja, the risk of bird fatalities is potentially high, especially for migratory gliders. In order to calculate the percentage of birds that pass through the rotor swept area level we divided the flight heights observed, in four flight level intervals, as follows: 0-50 m, 51-150 m, 151-500 m and over $500 \mathrm{~m}$. Also time intervals were divided into four hourly intervals, as follows: 7:00-10:00, 10:01-13:00, 13:01-16:00, 16:01-19:00 (local time).

All the data were collected using field observation sheets and subsequently entered into the Microsoft Excel electronic database. We used QuantumGIS ver. 2.18.12 in order to generate the migration heatmap for the Common Buzzard in Dobruja (Fig. 1).

\section{RESULTS AND DISCUSSIONS}

During this study we observed a total of 2,662 Common Buzzards from both subspecies that are present in the region (B. b. buteo and B. b. vulpinus). Out of them, 1521, representing $57 \%$ of the total number of individuals observed, have been identified as $B$. $b$. vulpinus, all of them being identified during autumn migration.

Spring migration was observed from 14 locations (Fig. 2). It begins in early March, and lasts until the end of April (Fig. 3). Migratory peaks during the spring remaining uncertain, probably between the end of March and the beginning of April (Cramp \& Simmons, 1987). Spring migration takes place in two waves, the first from the end of March to the first part of April, dominated mainly by adult individuals driven to breeding grounds, and a second wave after mid-April, dominated mainly by immature individuals (Forsman, 2010). The vast majority were observed migrating during the second time interval (10:01-13:00), representing 56\% of the total number, followed by $35 \%$ in the third interval (13:01-16:00), 6\% in the fourth interval (16:0119:00) and only 3\% in the morning, in the first interval (07:00-10:00) (Fig. 4). During

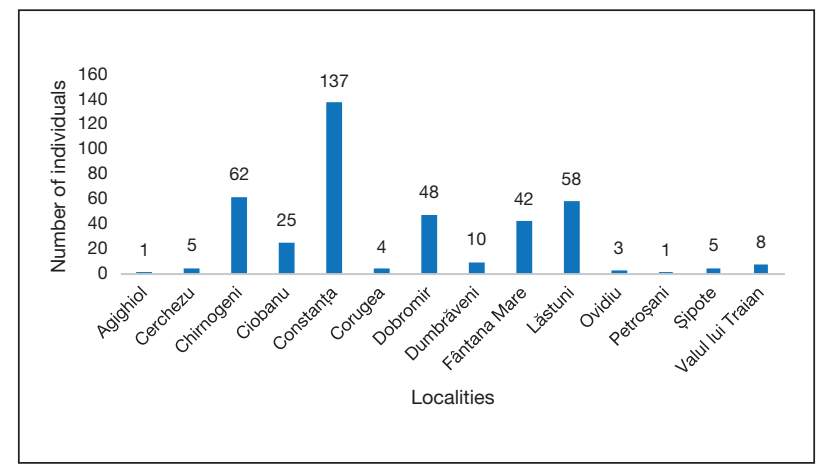

Fig. 2 - Number of Buteo buteo ssp. individuals reported from each location. 
the spring, the vast majority of buzzards, $61 \%$ were flying in the $151-500$ meter flight level interval (Fig. 5).

During the autumn migration, the largest number of Common Buzzard (878) was observed southwest the city of Constanța, near Bărăganu village, 875 being

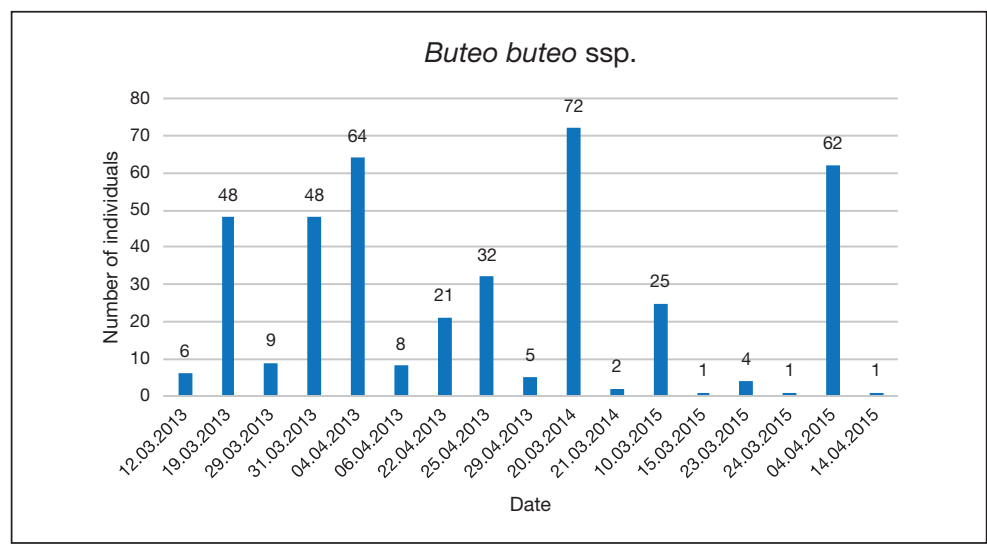

Fig. 3 - Migration peaks of Buteo buteo ssp. during spring.

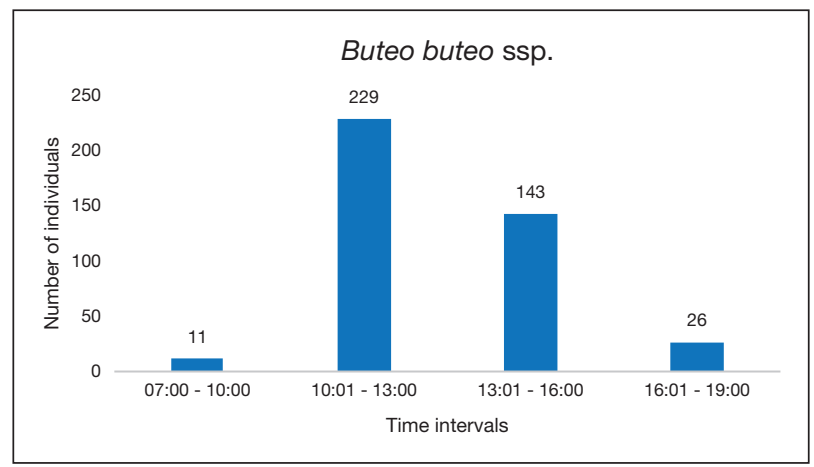

Fig. 4 - Migration time intervals of Buteo buteo ssp. during spring migration.

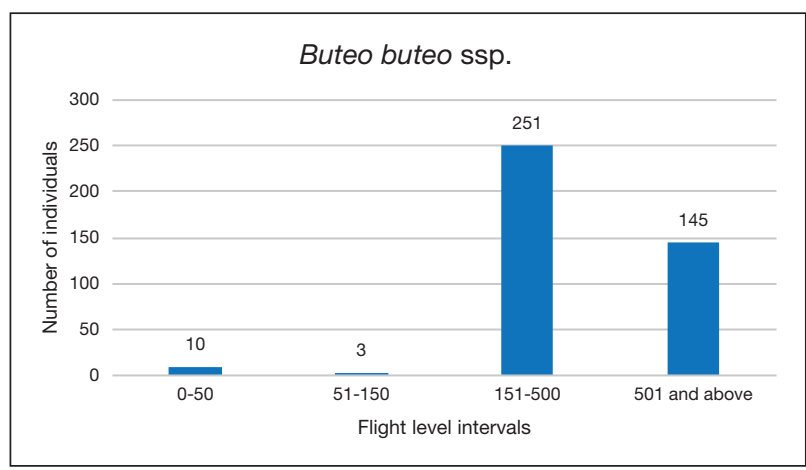

Fig. 5 - Flight level intervals of Buteo buteo ssp. during spring migration through Dobruja. 
identified as Buteo buteo vulpinus. Another hotspot is located in central Dobruja region (Târguşor locality, Constanţa County), with a total of 795 individuals of Buteo buteo spp. (Fig. 6). Our observations showed that the autumn migration of the Common Buzzard starts at the end of August, the peak of migration being reached between the $23^{\text {rd }}$ of September and the $6^{\text {th }}$ of October and ends at the beginning of November (Fig. 7). The vast majority were observed migrating during the second time interval (10:01-13:00), representing $41 \%$ of the total number, followed by the fourth interval (16:01-19:00) with $32 \%, 24 \%$ in the third interval (13:01-16:00) and only $3 \%$ in the morning, in the first interval (07:00-10:00) (Fig. 8). In autumn, Buteo buteo ssp. migrates mainly at low altitudes, in the first flight level interval of $0-50 \mathrm{~m}$, with a percentage of $81 \%$, compared to Buteo buteo vulpinus, that migrate mainly at high altitudes in the last interval of $500 \mathrm{~m}$ or above, with a percentage of $77 \%$ (Fig. 9).

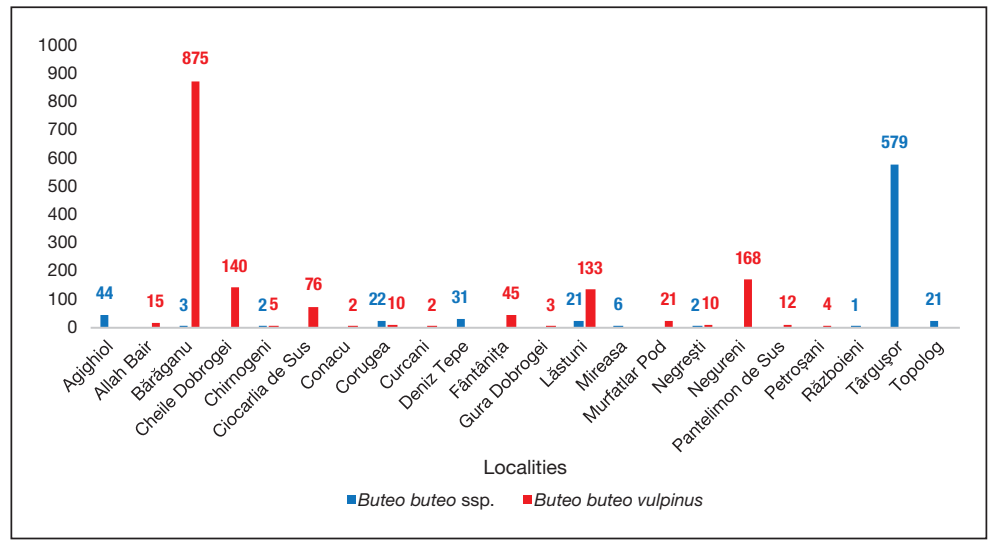

Fig. 6 - Number of Buteo buteo ssp. and Buteo buteo vulpinus individuals reported from each location.

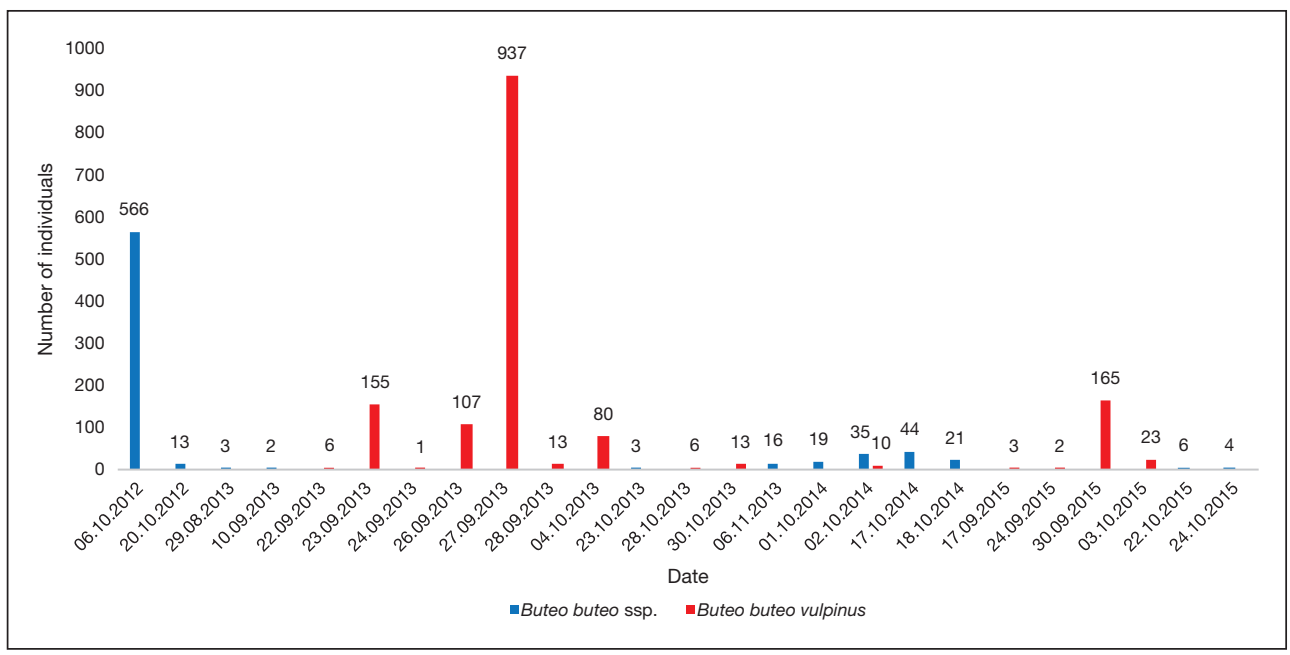

Fig. 7 - Migration peaks of Buteo buteo ssp. and Buteo buteo vulpinus during autumn. 


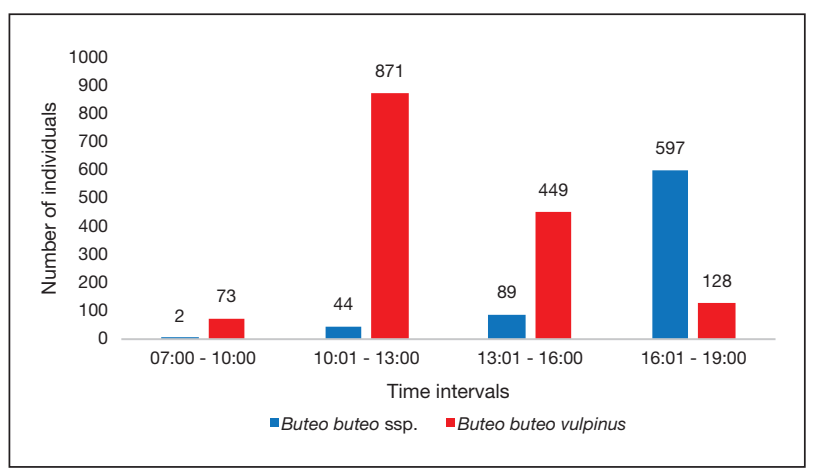

Fig. 8 - Migration time intervals of Buteo buteo ssp. and Buteo buteo vulpinus during spring migration.

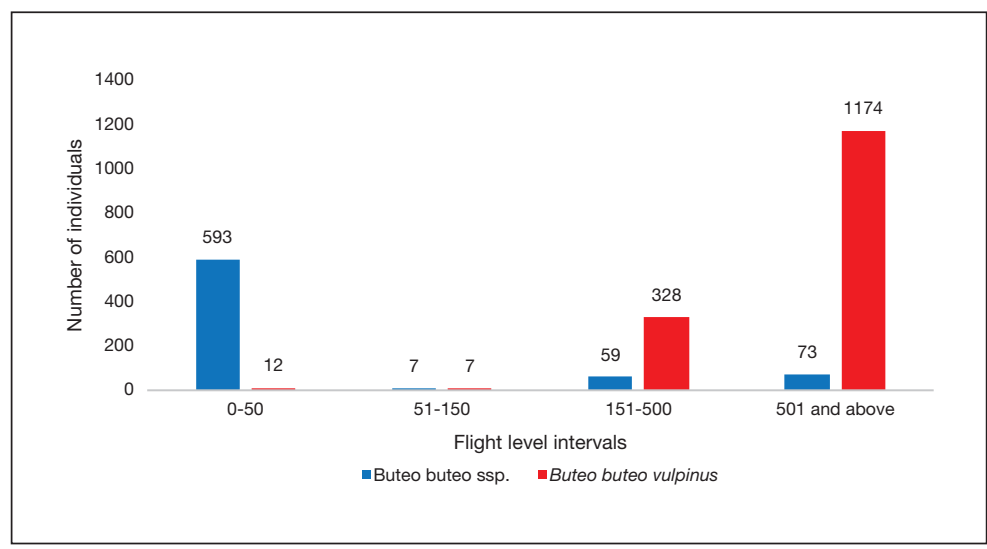

Fig. 9 - Flight level intervals of Buteo buteo ssp. and Buteo buteo vulpinus during autumn migration.

Regarding flight directions, we noticed that during the spring migration, the main direction is from South to North, but also from East-South-East to WestNorth-West. In a smaller proportion, we noticed individuals migrating South-West to North-East.

During the autumn migration we noticed two main directions, from North to South and from North-North-West to South-South-East, but also, in a smaller proportion from North-West to South-East, as shown in Fig. 10. We observed that the migration directions of this species through the Dobruja coincides with the main directions of winds, falling autumn predominantly from the North and North-East and in spring from South and South-East. At the same time, this species tale winds during migration, while $90 \%$ of migrating soaring birds from Messina region of Italy, of the genus Circus (harriers) and Pernis apivorus (honey buzzard), are using head winds to transit over the Strait of Messina while migrating South (Panuccio, 2011). Also Buteo buteo vulpinus migrates even when air currents are accompanied by rains, as observed at the monitoring station for raptor migration in Batumi, Georgia, where in October 2011, hundreds of common buzzards (vulpinus subspecies) passed over on a heavy rain (Panuccio, 2011). 


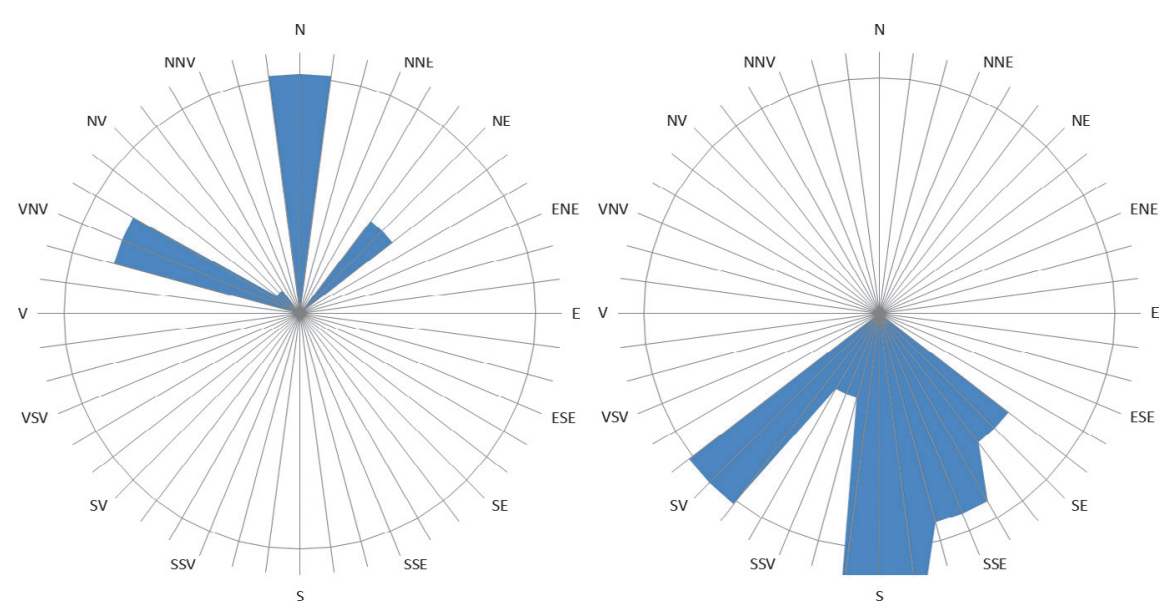

Fig. 10 - Dominant migration direction of Common Buzzard in Dobruja during autumn (left) and spring (right).

As far as the percentage of individuals flying at an altitude, where there is a risk of collision with wind turbine blades, is very low for this species, namely $1 \%$ of the Buteo buteo ssp. individuals observed in spring migration and $1 \%$ of Common Buzzards in autumn migration.

\section{Conclusions}

During the observation period, a total of 2,662 individuals were observed. Among them, 57\% could be identified as Buteo buteo vulpinus.

The main autumn passage direction was from $\mathrm{N}$ to $\mathrm{S}$, and NNW to SSE but also from NE to SW. For spring passage the main direction was from $\mathrm{S}$ to $\mathrm{N}$ but also from ESE to WNW.

Flight height during autumn migration was mostly at high altitude of over 500 $\mathrm{m}$ for Buteo buteo vulpinus, and mainly low altitudes for Buteo buteo ssp., while in spring migration was more evenly distributed (between 151-500 $\mathrm{m}$ and over 500m).

The most significant activity during the day was recorded in the second time period, between 10:01 and 13:00 (43\%).

The peek passage period in autumn migration was reached between the $26^{\text {th }}$ of September to the $6^{\text {th }}$ of October, while for the spring migration peek passage is uncertain (late march to early April).

In conclusion, we bring new data about the importance of Dobruja region in the migration of the Common Buzzard.

\section{ACKNOWLEDGEMENTS}

We are thankful to two anonymous reviewers for their valuable comments on improving the manuscript. A major part of this study was carried out with the support from Oceanographic Research and Marine Environment Protection Society Oceanic-Club. The study was partially funded by project no. RO1567-IBB04/2017 from the Institute of Biology Bucharest of Romanian Academy. 


\section{REFERENCES}

ALERSTAM, T. (1990) Bird migration. Cambridge University Press, 420 pp.

BILDSTEIN, K.L. (2006) Migrating Raptors of the World: Their Ecology and Conservation. Cornell University Press, $320 \mathrm{pp}$.

CĂTUNEANU, I., A. FILIPAŞCU, D. MUNTEANU, E. NADRA, V. POP, C. ROSETTI-BĂLĂNESCU, M. TẢLPEANU (1972) Nomenclatorul păsărilor din România. Ocrotirea Naturii, 16(1): 127-145. (in Romanian)

CRAMP, S. (ed.), K.E.L. SIMMONS (1987) Handbook of the birds of Europe, the Middle East and North Africa: The birds of the Western Palearctic. Vol. 2, Hawks to Bustards. Oxford University Press, $694 \mathrm{pp}$.

FORSMAN, D. (2010) The Raptors of Europe and the Middle East: A Handbook to Field Identification, Christopher Helm, London, 589 pp.

FORSMAN, D. (2016) Flight identification of raptors of Europe, North Africa and the Middle East, Christopher Helm, London, 544 pp.

GÉNSBØL, B. (2008) Collins Birds of Prey. Harper Collins Publisher Ltd. London. 414pp.

GWINNER, E. (1990) Bird migration: physiology and ecophysiology. Springer, Berlin

HOLTE, D., U. KÖPPEN, A. SCHMITZ-ORNE'S (2016) A comparison of migratory strategies of partial migratory raptors from Germany, Journal of Ornithology, 158(2): 579-592.

MELLER, K., A. LEHIKOINEN, AV. VÄHÄTALO (2013) The effects of hatching date on timing of autumn migration in partial migrants-an individual approach. Journal of Avian Biology, 44: $272-280$.

MOREAU, R. (1972) The Palearctic-African Bird Migration Systems. Academic Press. 384 pp.

NEWTON, I. (2010) Bird migration. Harper Collins Publishers

NISBET, I.C.T. (1962) Thermal Convection and Trans-Saharan Migration. Ibis, 104: 431.

PANUCCIO, M. (2011) Across and around a barrier: migration ecology of raptors in the Mediterranean baisin. Scientifica Acta 5, No. 1, Experimental Ecology and Geobotany: 27-36.

PAȘCOVSCHI, S., L. MANOLACHE (1971) Contribuții la studiul sistematic al șorecarului comun (Buteo buteo) (L.) din România. Muzeul de Științele Naturii Bacău, Studii și Comunicări, 231-244. (in Romanian)

SPAAR, R. (1997) Flight strategies of migrating raptors; a comparative study of interspecific variation in flight characteristics. Ibis 139: 523-535.

SPAAR, R., B. BRUDERER (1997) Optimal flight behavior of soaring migrants: a case study of migrating steppe buzzards, Buteo buteo vulpinus. Behavioral Ecology 8(3): 288-297.

STRANDBERG, R., T. ALERTAM, M. HAKE, N. KJELLEN (2009) Short-distance migration of the Common Buzzard Buteo buteo recorded by satellite tracking. Ibis 151: 200-206.

*** (2006) Batumi Raptor Count. http://www.batumiraptorcount.org, accesed at $5^{\text {th }}$ of March 2017

*** (2007) Raport de activitate. Evaluarea populațiilor de păsări din Parcul Național Munții Măcinului. Milvus Group - Bird and Nature Protection Association: www.parcmacin.ro, accesed at $5^{\text {th }}$ of March 2017. (in Romanian)

*** QGIS Development Team (2017) QGIS Geographic Information System. Open Source Geospatial Foundation. 